\title{
Public management overview of the construction and demolition waste from the municipality of São Paulo: challenges for the development of urban sustainability
}

\author{
S. H. Fukurozaki ${ }^{1}$, E. S. M. Seo ${ }^{1,2}$ \& S. R. H. Mello-Castanho ${ }^{1}$ \\ ${ }^{1}$ Institute for Energy and Nuclear Research, \\ Materials Science and Technology Centre, Brazil \\ ${ }^{2}$ University Centre of the National Service of Commercial Learning - \\ SENAC, Brazil
}

\begin{abstract}
The accelerated growth of the urbanization process aimed at the stabilization of the economy in recent years, brought to light the enormous quantity of construction and demolition waste $(\mathrm{C} \& \mathrm{DW})$ that has been created in the larger Brazilian cities. Considering the lack of and nearby adequate areas that might be available for the disposal of these materials, the appropriate management of C\&DW is currently one of the greatest challenges for the public administration. Within this context, this work presents an overview of the management of C\&DW in São Paulo, Brazil, after the creation of specific public regulations. As a conclusion, it shows that the institutions responsible for the legal regulations are disassociated from the command actions, control and economic incentives, in such a way that the simple creation of legislation is not sufficient to stop the inadequate disposal of C\&DW. In addition to this, there are also factors related to the market, environmental education, effective social control, absence of a structured public organization and public speeches from the key-persons involved in this area.
\end{abstract}

Keywords: public management, construction and demolition waste, urban development sustainability. 


\section{Introduction}

In April 1987, the expression "Sustainable Development" was coined in the Report of the World Commission for the Environment and Development, later denominated Our Common Future; it meant the development that fulfilled the needs of the present without compromising the capacity of future generations to, in turn, fulfill their own needs.

According to Donaire [1], the expression contains three fundamental points: economical growth, social equity and ecological equilibrium. Concretely, these new paradigms depend on production techniques and viable consumption for the environment in the long run. Besides the supply of services and products to attend the population's basic needs and provide better life quality, among others aspects, they also require reduced use of environmental resources and production of wastes.

In this sense, the rational management of construction and demolition waste (C\&DW) involves one of the strategic aims of the development of urban sustainability [3], considering that the construction industry is recognized as one of the most important activities for socioeconomic development, as well as a major cause of environmental impacts.

The accelerated urbanization, rapid increase in urban density and consequent depletion of nearby areas for C\&DW disposition, as well as the absence of public policies regulating and ordering the flows of C\&DW in São Paulo municipality, has caused serious catastrophic events in the urban environment. Among them, the covering of the drainage systems with C\&DW, occupation of roads and public areas by wastes, and the proliferation of disease transmitter agents.

In this context, this work presents an overview of the management of C\&DW after specific public policies were created, especially in São Paulo municipality, with the objective of bringing to light the challenges and furthering the knowledge on public management of construction waste.

The adopted methodology consisted in bibliographical and documental research, and the collection of data by site photography and by interviewing with agents involved in the private transport and disposal of C\&DW in São Paulo.

\section{The municipality of São Paulo and construction and demolition waste}

São Paulo is the most populous municipality in Brazil, with around 11 million inhabitants, and major financial center of the country. It is located in the São Paulo Metropolitan Area, which is known as the fourth biggest urban agglomerate of the world where around 17.8 million inhabitants live.

According to Shneider and Philippi [4], in 1994 the municipality urban area reached around $826.4 \mathrm{~km}^{2}$, which corresponded to $57.6 \%$ of the total extension of the municipal area. In 2002, the expansion, renewal and maintenance of the urban area resulted in the generation of 15000 tons of C\&DW per day approximately. The municipality possesses only three public units for C\&DW 
reception, two of which are Transfer Areas (ATT) destined to temporary storage, and the third is a specific landfill for final disposition [5]. According to the National Council for the Environment (CONAMA) and the Public Urban Cleaning (LIMPURB), around $81 \%$ of C\&DW was spilled irregularly in public areas of the municipality (figures 1 and 2).

A series of scenery deterioration effects can be observed, caused by that disposition, such as, compromising pedestrian and vehicle traffic and urban drainage, attraction of bulky domestic wastes, increase of various diseases [6].

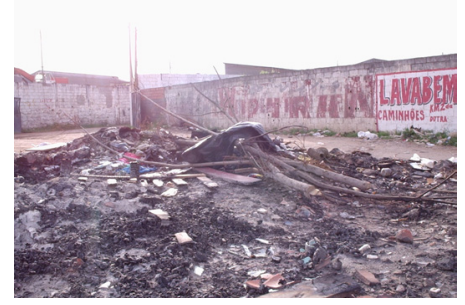

Figure 1: Example of irregular disposition in public areas of the municipal district of São Paulo, 2002.

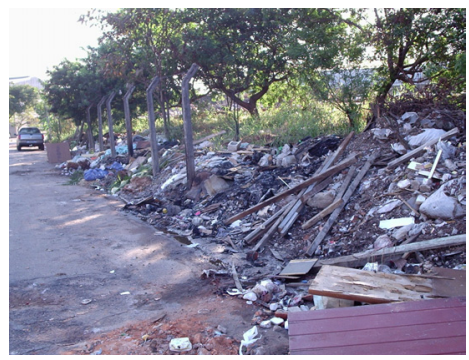

Figure 2: Example of irregular disposition in public areas of the municipal district of São Paulo, 2002.

In the above scenario, the agents usually involved are: the municipal government, responsible for the control and supervision of the transport and disposition of the wastes; the waste generators, building companies and builders; and the transporters, responsible for the removal, transport and disposition of C\&DW.

The actions taken by the municipal government against inadequate spilling of C\&DW, were limited to mere palliatives, as private companies were hired for collection services, transport and final disposition. According to Shneider and Philippi [4], given that these companies were to be paid by the number of runs carried out, tacit agreements were established with the transporters, so that there was not total removal of these wastes.

This also motivated the continuation of irregular disposal in the places reserved by the municipal management for urban waste, also caused by the C\&DW transporter, one of the main agents of the irregular disposition. Hence, 
the costs for the regular disposition at distant licensed areas were reduced hoping that the lower prices would favor those transporters that destined their wastes to those distant licensed areas. However, the lower prices also led the generators, mainly the builders, to choose those transporters, favoring the wastes irregular disposition.

This scenario and its consequences for the urban environment in the municipality of São Paulo, as well as in other Brazilian cities, and the urgent need for specific regulations about C\&DW, prompt CONAMA, at the federal extension level, to pass the resolution 307, in 2002, establishing guidelines and procedures for management of C\&DW.

That resolution defines, classifies and establishes the possible final destinations of $C \& D W$, and assigns responsibilities to the municipal government and the generators in what concerns its disposition. It therefore demands the elaboration of laws, mandates, judicial directives and other legal instruments from the municipality as part of the construction of public policies, so that it disciplines the C\&DW disposition.

Since then, the public authorities of both the municipality and the state of São Paulo have been concerned with the creation of policies for the effective reduction of the environmental impacts created by C\&DW. In the São Paulo state, the 13.478 Law and the resolution 41 of the State General Office for the Environment (SMA) regulate the organization of the Urban Cleaning System and establish the procedures for environmental landfill licensing for inert and construction industry wastes, respectively.

At the municipal level, the 13.298 Law defines the responsibilities of the C\&DW generators and collectors, and the 42.217 Mandate regulates the 10.315 Law in its application to the areas of Transfer and Selection of C\&DW and bulky wastes, carried out by private enterprises.

Also technical standards were created, integrated in the public policies, to enable the correct handling of the wastes in specific areas, namely:

$\checkmark$ NBR 15112 - Areas of Transfer and Selection - Guidelines for design, implantation and operation;

$\checkmark$ NBR 15113 - Landfill - Guidelines for design, implantation and operation;

$\checkmark \quad$ NBR 15114 - Recycling Areas - Guidelines for design, implantation and operation;

$\checkmark$ NBR 15115 - Recycled Aggregates from solid wastes of the construction industry - Execution of paving layers/procedures;

$\checkmark$ NBR 15116 - Recycled Aggregates from solid wastes of the construction industry - Use in paving and preparation of concrete without structural function/procedures;

Although recent, the current legislation expects to promote the change in general procedures in removal and disposition of C\&DW by supportive actions to the traditional and new agents. In other words, the minimization of raw 
materials' consumption by C\&DW valorization, better use of the public budget resources to invest in the solution of causes and problems, urban cleaning and public health improvement.

\section{Actual prospect of the public management of C\&DW}

In 2005, the construction activity in the urban area of the municipality of São Paulo generated around 17240 tons/day of C\&DW [7], and nowadays, a significant fraction of that mass of residues continues to be deposited irregularly in public areas, indicating the persistence of irregular dispositions in spite of the intense preparation of laws, mandates, resolutions and standards (figure 3).

The persistence of the inadequate disposition of C\&DW is firstly due to the behavior of the transporters. To reduce the expenses with fuel and truck maintenance, items directly related to the distance of the C\&DW transport and that account for $\sim 40 \%$ of the total cost of the activity, transporters keep discarding the material in public areas as they use to, before the creation of the municipal laws.

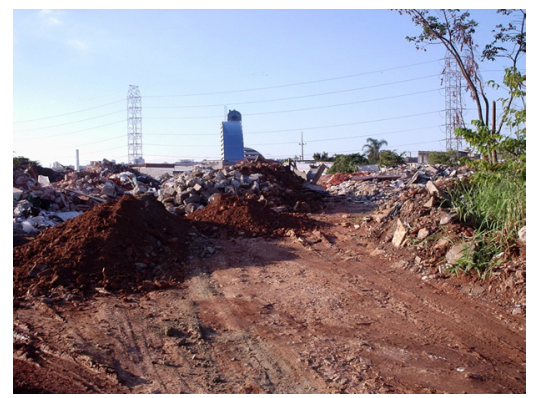

Figure 3: Example of the persistence of irregular C\&DW disposition in São Paulo, 2004.

However, the factors that affect the continuity of these depositions are not limited to the distance to legal sites and the tacit agreements among transporters and City Hall contracted companies for removal of C\&DW from public roads, but also include other sequentially related aspects:

$\checkmark$ The current activity in licensing demands pending at the municipal government;

$\checkmark$ The temporary disposition volume limitation in the landfill and public transfer areas and the introduction of disposition charges;

$\checkmark$ The service offer and demand in the market and deficient inspection.

The first mentioned aspect refers to the recent demand from LIMPURB that the trucks, besides being registered, should be inspected annually by the National Metrology and Industrial Standards Institute (INMETRO), going through 
rigorous equipment inspection procedures [8]. This request and related laws, for part of this segment translate into even larger annual service costs [9].

However, "Being licensed is no guarantee that the wastes will go to the municipal landfill, or to the two licensed transfer and selection areas (ATT). Yesterday, the Afternoon Journal (JT) showed as much, during a police raid in the irregular landfill at the Damasceno Garden, North Area, and the secretary Walter Feldman found a registered bucket" [10].

Because of this, in 2003 the municipal government established a discard quota for the company carriers and for the ATTs registered in LIMPURB. The established quota value, for each agent, was calculated as a function of the corresponding discharged ton average.

This quota system constrained the activity of both the transporters and, mainly, the ATTs. In periods of great construction activity, it was not possible to deposit material beyond the established individual limit, in the landfill and public transfer areas [5], and waste hips remained, in the same way, in road borders waiting for collection.

This scenario led to an increase in the C\&DW reception charge in private ATTs, that didn't necessarily implicate an increase of the area agents profit, because these, as well as the transporters, could not deposit C\&DW in the public landfill due to the quotas stipulated by LIMPURB, culminating in some cases in the refusal of material reception by the ATT [11].

The imposed limitation did not just restrict the transporters. The ATTs were also attributed daily material reception quotas by the public transfer areas. When the local daily limit was reached in the morning, for example, the transporters that arrived in the afternoon were forced to find another place to deposit the material, what increased the cost of the transport even further.

This situation still did not improve in 2004, when the quotas were removed and public C\&DW reception units started to charge U\$1.06 per ton of deposited waste. On the contrary, it added to the other incentives for irregular discarding, because the transporters did not review the discharge costs charged to the generators [12]. Moreover, the price raise applied in the beginning of 2006 only reinforced the decision for irregularity: "This raise will stimulate clandestine discharge because we don't get profit... with the raise, the price of the municipal transfer area was leveled with the private ones". "Nobody will pay", declared one of the transporters who threatened to "stop the city" in protest against the raise [12].

Other factors, such as the time schedules allowed for traffic, placement or removable of C\&DW' buckets from the public roads in certain areas of the city, in addition to the period of operation of the appropriate destination areas, and inspection absence, also favored the irregular disposition in public areas during the night and the dawn period.

However, although the transporters were, in the beginning, also blamed for the continuity of the urban environmental degradation, their actions are not dissociated from the behavior of the generators and the public government. About $75 \%$ of the waste generated by construction comes from informal events 
(construction, reforms and demolition works, usually carried out by the builders themselves).

C\&DW participates, between $15 \%$ and $30 \%$ of the total mass, in the traditional construction and this, although gradually, has been acting in a proactive way and is responsible for the reduction, recycling and correct final disposition of the generated wastes. This corresponds to significant economical benefits, characterized by the reduction of loss and consumption of raw materials and legal settlements [13].

The same does not happen with the activity of the small generators, if they choose to favor the lowest price for C\&DW' removal and transport. This also promotes the clandestine activity and irregular deposition: "the problem of irregular discard exists because many people negotiate, instead of registered companies, with transporters willing to charge less" [10].

Along with the dissemination of the builders' construction and demolition activity and the ignorance of their responsibilities as C\&DW' generators, comes the difficulty of public government inspection, which also suggests the knowledge absence about the observance of the directives in the specific legislation.

In what concerns the performance of the municipal public government, it can be observed that the urban cleaning' management presents, in this respect, deficient physical structures and management to exercise the command actions and control directives specified by the legislation. According to the secretary of Services and Works of the City Hall, "the Urban Cleaning Department, responsible for the inspection of the collection companies of the solid wastes, consists of ten inspectors, only" [10].

Adding to the above reasoning, other factors related to the absence of economical instruments [5], full knowledge of the social logic [4] and prevalence of corrective actions in detriment of preventive ones in what concerns C\&DW disposition, also influence all agents involved to perpetuate this scenario of urban degradation.

\section{Conclusions}

This work showed that the simple establishment of legal directives in the São Paulo municipality was not enough to prevent the inadequate disposition of $\mathrm{C} \& \mathrm{DW}$, and should be accompanied by a restructuring in the whole management department of the public government, so that its responsibilities before the Law can be exercised fully.

In addition, the persistence of a scenario of urban environmental degradation, the inexistence of economical instruments and environmental education that motivate a responsible behavior from small generators and transporters, as well as the ignorance of factors that affect the C\&DW the collection and transport market was clearly observed. In this perspective, the challenges for a sustainable urban development can be summarized as follows:

$\checkmark$ Structuring of the municipal public government and the consequent efficient inspection; 
$\checkmark$ Creation of economical instruments;

$\checkmark$ Introduction of environmental education programs;

$\checkmark$ Improvement of the knowledge of the factors that influence the market.

From this point of view, the interrelations among the civil society, government and private departments indubitably contribute to the construction of the scenario of urban environmental degradation. This way, public politics should be as more concrete as the larger is the community's influence in the conduction of the public mandate. The community's actions as history protagonists redefine the priorities and lead the government to the establishment of effective social control.

Finally, the consolidation of solid politics is one of the conditions so that the necessary progresses are channeled in the direction to transcend the scenario of environmental degradation and uncontrolled use of natural resources that should be preserved for the next generations.

\section{Acknowledgements}

The authors wish to acknowledge the FAPESP - The State of São Paulo Research Foundation and $\mathrm{CNPq}$ - The National Council for Scientific and Technological Development, both of Brazil Government for financial support. The persons who contributed information to this paper, especially the managers of the C\&DW transport, reception companies and Dr. A. M. Segadães for useful suggestions.

\section{References}

[1] Donaire, D. Gestão ambiental na empresa. São Paulo: Ed. Atlas, pp.172, 1995.

[2] SMA. Secretaria de Estado do Meio Ambiente. A cidade e o lixo. São Paulo: Secretaria de Estado de Meio Ambiente - CETESB, 1998a.

[3] Blumenschein, R. N. Gerenciamento de resíduos sólidos oriundos da indústria da construção. www.nepam.br/ecoeco/artigos.

[4] Shneider, D.M. \& Philippi Jr., A. Gestão Pública de resíduos da construção civil no município de São Paulo. Ambiente Construído, Porto Alegre, v.4, n.4, p.21-32, out. /dez. 2004.

[5] Fukurozaki, S. H. \& Seo, E.S.M. Desafios para a destinação de resíduos da construção civil: a implantação das áreas de transbordo e triagem no município de São Paulo. Anais do Congresso Brasileiro de Ciência e Tecnologia de Resíduos e Desenvolvimento Sustentável - ICTR. ICTR: Núcleo de Informações em Saúde Ambiental da USP - NISAN: Florianópolis, pp.4750-4759, 2004.

[6] Pinto, T. P. Metodologia para a gestão diferenciada de resíduos sólidos da construção urbana. Tese de doutorado.Escola Politécnica da Universidade de São Paulo. São Paulo, pp.189, 1999. 
[7] Pinto, T. P. (coord). Gestão Ambiental de resíduos da construção civil: a experiência do SindusCon -SP. São Paulo: Obra limpa: I\&T: SindusCon -SP, pp.48, 2005.

[8] Limpnet, www.limpnet.com.br/default11.asp

[9] Private communication.

[10] SindusCon, www.sindusconsp.com.br/secao/interna.asp?id=11602

[11] Filho, P. M. Comunicação Pessoal, 20 de novembro de 2005.Gerente. Área de Transbordo e Triagem da Vila Guilherme.

[12] OGlobo.www.oglobo.globo.com/online/sp/plantao/2006/02/03/19157239 5.asp

[13] Recicláveis. www.reciclaveis.com.br/noticias/00411/0041116entulho.htm. 